\title{
Efektivitas Penataan Parkir Di Badan Jalan Terhadap Peningkatan Kinerja Ruas Jalan Studi Kasus Jalan Ir.H Juanda Kota Sukabumi
}

\author{
Rani Wijayanti ${ }^{1}$, Agus Budi Purwantoro², Sutardjo ${ }^{3}$ \\ Program Studi Manajemen Keselamatan Transportasi Jalan \\ Politeknik Keselamatan Transportasi Jalan Tegal \\ E-mail: ranywijayanti7@gmail.com
}

Received 6 Oktober 2020; 31 Oktober 2020; 10 November 2020

Journal Homepage: http://ktj.pktj.ac.id/index.php/ktj

DOI: $10.46447 / k t j . v 7 i 2.285$

\begin{abstract}
ABSTRAK
Ruas Jalan Ir.H. Juanda Kota Sukabumi merupakan kawasan komersial dan kawasan pendidikan dengan lokasi parkir yang berada di jalan (on street). Permasalahan mengenai parkir yang ada pada ruas jalan tersebut memberikan dampak terhadap kapasitas jalan yang ada. Parkir yang tidak tertata dengan rapi membuat kinerja ruas jalan tersebut menjadi kurang baik. Metode yang digunakan dalam penelitian ini adalah dengan menggunakan perhitungan kinerja ruas jalan berdasarkan MKJI 1997. Perhitungan kinerja parkir menggunakan perhitungan karakteristik parkir hingga indeks parkir serta penentuan pola parkir berdasarkan Pedoman Teknis Fasilitas Parkir. Hasil dari penelitian ini adalah direkomendasikan untuk penetapan pola parkir untuk kendaraan roda 4 dari sudut $0^{\circ}$ menjadi sudut $45^{\circ}$ dikarenakan hal ini akan lebih menerima kapasitas kendaraan lebih banyak dan pola parkir sudut $90^{\circ}$ menjadi sudut $45^{\circ}$ untuk kendaraan sepeda motor. Perubahan sudut parkir mempengaruhi perubahan jumlah SRP menjadi 57 petak untuk SRP kendaraan ringan. Sedangkan berdasarkan analisis yang dilakukan 2 SRP kendaraan ringan dapat digunakan untuk 10 SRP sepeda motor. Jumlah SRP yang dihasilkan setelah dilakukan perubahan sudut adalah 135 petak untuk sepeda motor dan 30 petak untuk kendaraan ringan.
\end{abstract}

Kata kunci: Parkir Badan Jalan, Kinerja Ruas Jalan, Kinerja Parkir.

\section{PENDAHULUAN}

Salah satu permasalahan yang terkait dengan sektor transportasi di Indonesia adalah aktivitas parkir di badan jalan (on street parking). Permasalahan tersebut semakin meningkat, sejalan dengan tingkat pertumbuhan populasi, pesatnya tingkat pertumbuhan jumlah kendaraan dan kepemilikan kendaraan, serta sistem angkutan umum yang kurang efisien sehingga akan berdampak kepada turunnya tingkat kinerja ruas jalan. Hal ini dipengaruhi lagi dengan adanya kendaraan yang melakukan kegiatan parkir di badan jalan yang menyebabkan terbatasnya ruang lalu lintas.

Perparkiran merupakan masalah yang sering dijumpai dalam sistem transportasi. Masalah perparkiran akhir-akhir ini terasa sangat mempengaruhi pergerakan kendaraan, dimana kendaraan yang melewati tempat yang mempunyai aktivitas tinggi laju pergerakannya akan terhambat oleh kendaraan yang parkir di badan jalan, sehingga hal ini dapat menyebabkan kemacetan (Puspitasari, 2017). 
Adanya kondisi ketersediaan lahan parkir kendaraan pengunjung yang terbatas menyebabkan terjadinya parkir di badan jalan. Kondisi ketiadaan ruang parkir menyebabkan jalan dijadikan sebagai tempat parkir kendaraan. Kebijakan mengenai larangan parkir di badan jalan dimuat dalam Undang-Undang Nomor 22 Tahun 2009 tentang Lalu Lintas Jalan yang melarang penggunaan badan jalan dan trotoar, antara lain, sebagai tempat parkir. Sebelumnya juga sudah ada aturan Undang-undang Nomor 38 Tahun 2004 serta Peraturan Pemerintah Nomor 34 Tahun 2006 tentang Jalan, yang tidak membenarkan penggunaan badan jalan maupun trotoar sebagai lahan parkir.

Di Kota Sukabumi zona larangan parkir tertuang dalam Pasal 28 Perda Kota Sukabumi Nomor 5 Tahun 2018 tentang Penyelenggaraan Perhubungan. Perda ini merujuk pada Undang-Undang Nomor 22 Tahun 2009 tentang Lalu Lintas dan Angkutan Jalan. Jalan Ir.H. Juanda Kota Sukabumi merupakan ruas jalan dengan fungsi jalan lokal primer. Jalan ini terletak di pusat kota Sukabumi dan merupakan kawasan sarana perdagangan, sarana pendidikan, dan sarana perkantoran yang ramai di kunjungi oleh masyarakat Kota Sukabumi. Sehingga sering terjadi konflik dari pergerakan arus lalu lintas yang mengakibatkan terhambatnya lalu lintas dan ketidakteraturan di sepanjang ruas Jalan Ir.H. Juanda Kota Sukabumi yang diakibatkan oleh keberadaan parkir badan jalan (on street parking).

\section{METODE PENELITIAN}

Penelitian ini dilakukan di ruas Jalan Ir.H Juanda Kota Sukabumi dengan fungsi jalan kolektor sekunder dan status jalan yaitu jalan Kota. Ruas Jalan Ir.H. Juanda Kota Sukabumi memiliki panjang \pm 250 m dengan tipe jalan 4/2 D. Berikut adalah bagan alir penelitian ditunjukkan pada gambar 1 dibawah ini:

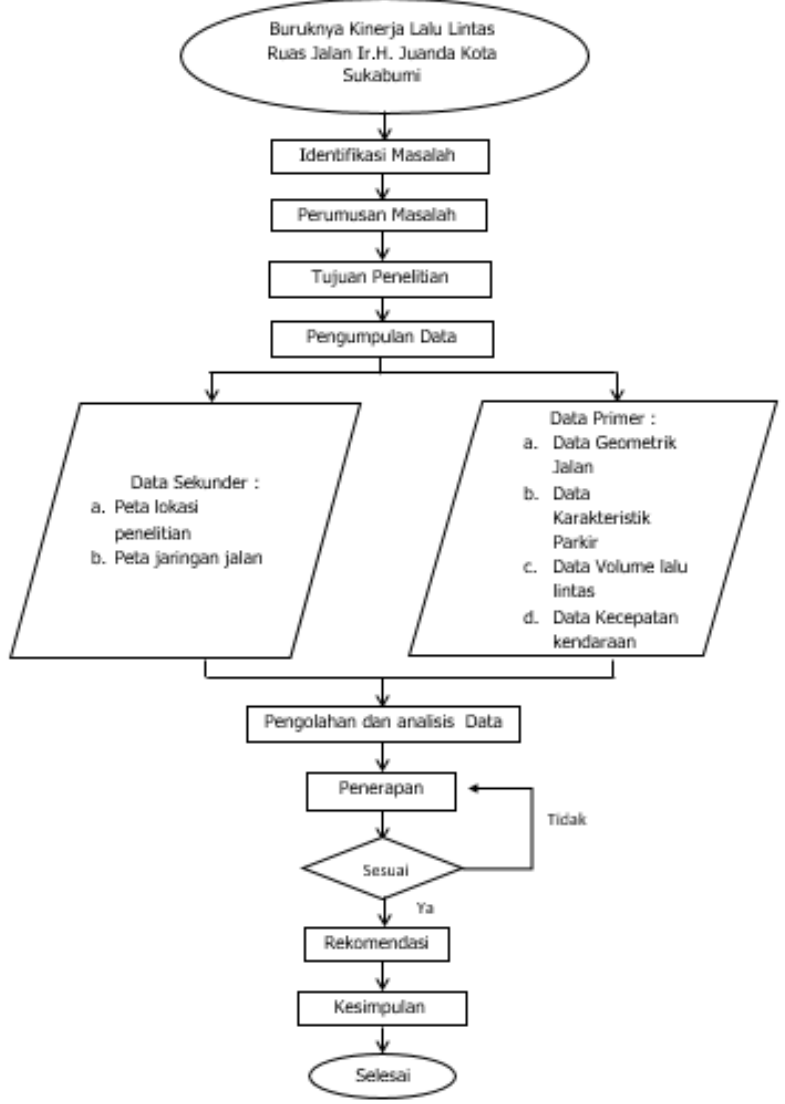

Gambar 1. Bagan Alir Penelitian 


\section{Teknik Pengumpulan Data}

a. Data Geometrik Jalan

Metode yang digunakan dalam pengumpulan data inventarisasi jalan dengan cara dokumentasi atau pengambilan gambar dan pengukuran, yaitu dengan mengukur jarak dengan menggunakan Walking Meassure. Data yang dicari berupa panjang jalan, lebar jalan, lebar bahu jalan, lebar trotoar, panjang area parkir, dan lebar area parkir. Untuk data perlengkapan jalan berupa rambu lalu lintas yang ada, marka jalan, dan penerangan jalan umum.

b. Data Volume Lalu Lintas

Data volume lalu lintas didapatkan dengan melakukan survei Traffic Counting untuk menghitung kendaraan yang melewati Jalan Ir.H. Juanda Kota Sukabumi yang dilakukan saat jam sibuk. Berdasarkan volume lalu lintas terklarifikasi yang mencakup jenis kendaraan dan arah perjalanan.

c. Data Kecepatan

Survei kecepatan di dalam penelitian ini adalah untuk mengetahui kecepatan yang digunakan oleh kendaraan pada saat melintasi ruas Jalan Ir.H. Juanda. Survei ini dilakukan dengan cara menggunakan alat pengukur kecepatan yaitu Speedgun. Pengambilan data hanya perlu berdiri di titik pengamatan kemudian menembakkan ke kendaraan yang hendak diukur kecepatannya.

d. Data Karakteristik Parkir

1. Data Masuk dan Keluar Kendaraan Parkir Pengambilan data ini dengan melakukan pengamatan dan pencatatan kendaraan yang masuk atau keluar parkir pada lokasi yang terdapat area parkir badan jalan selama waktu tertentu. Waktu pengamatan dimulai dari pukul 06.00-18.00 WIB. Pencatatan yang dilakukan berupa jumlah kendaraan yang masuk dan keluar parkir serta plat nomor dari kendaraan tersebut.

2. Data durasi parkir dilakukan dengan pengamatan dan pencatatan lamanya kendaraan yang parkir pada lokasi-lokasi yang terdapat area parkir badan jalan selama waktu tertentu. Pencatatan yang dilakukan berupa lamanya kendaraan parkir dari masuk sampai keluar parkir.

\section{Teknik Analisis Data}

a. Volume Lalu Lintas

Analisis volume dilakukan dengan cara menghitung jumlah kendaraan yang melewati ruas Jalan Ir.H. Juanda Kota Sukabumi melalui hasil survei traffic counting. Analisis volume lalu lintas dalam satuan kendaraan per jam dikonversi dalam smp/jam.

b. Kapasitas Jalan

Metode yang digunakan adalah Manual Kapasitas Jalan Indonesia (MKJI 1997), untuk menghitung derajat kejenuhan ruas jalan tersebut. Setelah mendapatkan perhitungan dari kinerja ruas jalan maka dapat diketahui tingkat pelayanan jalan berdasarkan PM 96 Tahun 2015 tentang Pedoman Pelaksanaan Kegiatan MRLL.

$\mathrm{C}=$ Co $\times$ FCW $\times$ FCsp $\times$ FCsf $\times$ FCcs

C : Kapasitas (smp/jam), Co : Kapasitas dasar (smp/jam), FCw: Faktor penyesuaian lebar jalan, FCsp: Faktor penyesuaian pemisah arah, FCsf: Faktor penyesuaian hambatan samping dan bahu jalan/kerb dan FCcs :

Faktor penyesuaian ukuran kota 
c. Kecepatan Lalu Lintas

Untuk mengetahui kecepatan kendaraan yang melintas di ruas Jalan Ir.H Juanda dilakukan pengukuran dengan menggunakan jarak dibagi dengan waktu untuk mengetahui kecepatan kendaraan. Perhitungan sampel dilakukan untuk menentukan jumlah kendaraan yang nantinya untuk melakukan survei kecepatan. metode yang digunakan untuk menentukan jumlah sampel adalah menggunakan rumus Slovin :

$$
\begin{aligned}
& n=\frac{N}{1+N(e)^{2}} \\
& \mathrm{n}: \text { Jumlah sampel, } \mathrm{N}: \text { Ukuran populasi e : Batas toleransi kesalahan }
\end{aligned}
$$

d. Karakteristik Parkir

1. Volume parkir adalah jumlah kendaraan yang termasuk dalam beban parkir, yaitu jumlah kendaraan per periode waktu tertentu (umumnya per hari).

Volume $=\mathrm{Nm}+\mathrm{X}($ Kend $)$

$\mathrm{Nm}$ : Jumlah kendaraan masuk, $\mathrm{X}$ : Kendaraan yang sudah ada sebelum waktu survey

2. Akumulasi parkir dapat dibagi sesuai dengan kategori jenis atau maksud perjalanan, serta integrasi dari akumulasi parkir selama periode tertentu menuju beban parkir (jumlah kendaraan parkir). Akumulasi parkir ini dapat dijadikan ukuran kebutuhan ruang parkir di loaksi studi.

$\mathrm{AP}=(\mathrm{X}+\mathrm{Ei})-\mathrm{EX}$

AP : Akumulasi parkir (kend), $\mathrm{X}$ : Kendaraan yang sudah ada sebelum waktu survei, Ei : Jumlah kendaraan yang masuk ke tempat parkir (kend), Ex : Jumlah kendaraan yang keluar tempat parkir (kend)

3. Kapasitas Parkir merupakan kemampuan maksimum ruang tersebut dalam menampung kendaraan, dalam hal ini adalah volume kendaraan pemakai fasilitas parkir.

$K P=\frac{S}{D}$

KP : Kapasitas parkir (kend/jam), S : Jumlah petak parkir yang tersedia dilokasi penelitian, D : Waktu rata-rata lama parkir (jam/kend)

4. Indeks parkir adalah perbandingan antara akumulasi parkir dengan kapasitas parkir. Nilai indeks ini dapat menunjukkan seberapa besar kapasitas parkir yang telah terisi.

$I P=\frac{\text { Akumulasi Parkir }}{\text { Kapasitas Parkir }}$

IP $<1$ artinya bahwa fasilitas parkir tidak bermasalah, dimana kebutuhan parkir tidak melebihi daya tampung/kapasitas normal, IP $=1$ artinya bahwa kebutuhan parkir seimbang dengan daya tampung/kapasitas normal, IP > 1 artinya bahwa fasilitas parkir bermasalah sebab kebutuhan parkir melebihi daya tampung/kapasitas normal

\section{HASIL DAN PEMBAHASAN Geometrik Jalan}

Ruas jalan Ir.H. Juanda memiliki karakteristik dengan lalu lintas padat terutama pada pagi dan sore hari karena terkena dampak dari aktivitas sekolah, perkantoran, warung makan dan juga para penjual kaki lima yang berada di 
sepanjang ruas jalan Ir.H. Juanda Kota Sukabumi, dan pada ruas jalan tersebut tidak memiliki lahan off street parking untuk kendaraan baik sepeda motor maupun kendaraan roda 4.

Panjang jalan pada ruas jalan Ir.H Juanda adalah \pm 250 meter, ruas jalan tersebut berada di kawasan Pusat Pemerintahan Kota Sukabumi dan DPRD Kota Sukabumi. Selain itu juga merupakan kawasan komersial dan pendidikan. Pada lokasi penelitian memiliki tipe jalan 4/2D atau 4 lajur 2 arah terbagi dan memiliki lebar jalan 15,6 meter dimana terdapat parkir badan jalan pada salah satu sisi yaitu sisi jalan sebelah barat.

\section{Perlengkapan Jalan}

Perlengkapan jalan yang ada di ruas jalan Ir.H Juanda adalah perambuan, lampu penerangan jalan umum (LPJU) dan marka jalan.

Tabel 1. Data Geometrik Jalan

\begin{tabular}{|c|c|c|c|}
\hline No & STA & Penempatan & Keterangan \\
\hline 1 & $0+00$ & Sisi timur & $\begin{array}{l}\text { Rambu petunjuk jalan dan rambu } \\
\text { larangan parkir }\end{array}$ \\
\hline 2 & $0+3,2$ & Median jalan & $\begin{array}{l}\text { Rambu perintah lajur yang boleh } \\
\text { dilewati dan rambu larangan masuk } \\
\text { bagi semua kendaraan }\end{array}$ \\
\hline $\begin{array}{l}3 \\
4\end{array}$ & $\begin{array}{l}0+39,4 \\
0+53,3\end{array}$ & $\begin{array}{l}\text { Sisi timur } \\
\text { Sisi barat }\end{array}$ & $\begin{array}{l}\text { Rambu dilarang parkir } \\
\text { Rambu peringatan banyak anak-anak }\end{array}$ \\
\hline $\begin{array}{l}5 \\
6\end{array}$ & $\begin{array}{l}0+64,9 \\
0+101,3\end{array}$ & $\begin{array}{l}\text { Sisi barat } \\
\text { Sisi timur }\end{array}$ & $\begin{array}{l}\text { Rambu petunjuk parkir } \\
\text { Papan informasi tarif retribusi parkir }\end{array}$ \\
\hline 7 & $0+189,3$ & Sisi timur & $\begin{array}{l}\text { Rambu dilarang parkir dengan kondisi } \\
\text { tertutup pohon }\end{array}$ \\
\hline 8 & $0+214,0$ & Sisi barat & $\begin{array}{l}\text { Rambu petunjuk parkir kendaraan } \\
\text { roda } 4 \text { dan APILL }\end{array}$ \\
\hline 9 & $0+219,6$ & Sisi timur & $\begin{array}{l}\text { Rambu peringatan banyak anak-anak } \\
\text { dengan kondisi tulisan memudar }\end{array}$ \\
\hline 10 & $0+243,8$ & Sisi timur & $\begin{array}{l}\text { Rambu petunjuk lokasi fasilitas } \\
\text { pendidikan }\end{array}$ \\
\hline
\end{tabular}

Sumber : Hasil Analisis, 2020

\section{Volume Lalu Lintas}

Volume lalu lintas dimana jenis kendaraan yang melewati ruas jalan Ir.H Juanda tersebut terdiri dari LV, MC dan UM. Survei Traffic Counting dilakukan selama 12 jam. Dari hasil survei yang dilakukan, didapatkan bahwa jam tersibuk yaitu pada jam $16.00-17.00$ WIB. Dari hasil perhitungan total smp/jam tertinggi pada hari kerja berada pada pukul $16.00-17.00$ WIB yaitu 642,1 smp/jam. Pada jam tersebut merupakan jam sibuk lalu lintas di ruas Jalan Ir.H Juanda Kota Sukabumi dengan komposisi lalu lintas MC, LV dan UM. Sedangkan volume kendaraan dua arah pada hari libur tertinggi terjadi pada pukul $16.00-17.00$ WIB yaitu sebesar 209,1 smp/jam, dan volume kendaraan terendah terjadi pada pukul 07.00 WIB - 08.00 WIB sebesar 32,8 smp/jam. 


\section{Kecepatan Kendaraan}

Data kecepatan kendaraan yang melintas pada jalan Ir.H. Juanda didapatkan dengan melakukan pengukuran waktu tempuh kendaraan yang melintasi jarak yang sudah ditentukan yaitu pada hari kerja dan hari libur, kemudian dilakukan perhitungan agar mendapatkan nilai dari kecepatan kendaraan.

Tabel 2. Kecepatan Kendaraan Hari Kerja

\begin{tabular}{cccccc}
\hline \multirow{2}{*}{$\begin{array}{c}\text { Arah } \\
\text { kendaran }\end{array}$} & Jenis & Jumlah & \multicolumn{3}{c}{ Kecepatan $(\mathbf{K m} /$ Jam) } \\
\cline { 5 - 6 } Kendaraan & Sampel & Tertinggi & Terendah & Rata-Rata \\
\hline \multirow{3}{*}{ Arah Barat } & MC & 260 & 55 & 23 & 38 \\
& LV & 81 & 47 & 22 & 35 \\
& UM & 3 & 28 & 25 & 26 \\
\hline \multirow{3}{*}{ Arah Timur } & MC & 238 & 49 & 25 & 40 \\
& LV & 136 & 54 & 23 & 37 \\
& UM & 1 & 23 & 23 & 23 \\
\hline
\end{tabular}

Sumber : Hasil Analisis, 2020

Pada hari kerja kecepatan rata-rata dari arah barat yaitu kendaraan MC 38 $\mathrm{km} / \mathrm{jam}$, LV $35 \mathrm{~km} / \mathrm{jam}$, dan UM $26 \mathrm{~km} / \mathrm{jam}$. Untuk arah timur kecepatan ratarata yaitu kendaraan MC 40 km/jam, LV 37 km/jam, dan UM 23 km/jam.

Tabel 3. Kecepatan Kendaraan Hari Libur

\begin{tabular}{cccccc}
\hline \multirow{2}{*}{$\begin{array}{c}\text { Arah } \\
\text { kendaran }\end{array}$} & Jenis & Jumlah & \multicolumn{3}{c}{ Kecepatan $(\mathbf{K m} /$ Jam $)$} \\
& Kendaraan & Sampel & Tertinggi & Terendah & Rata-Rata \\
\hline \multirow{3}{*}{ Arah Barat } & MC & 112 & 55 & 28 & 39 \\
& LV & 52 & 47 & 24 & 37 \\
& UM & 4 & 26 & 22 & 23 \\
\hline \multirow{3}{*}{ Arah Timur } & MC & 136 & 53 & 24 & 38 \\
& LV & 47 & 50 & 28 & 38 \\
& UM & 10 & 29 & 24 & 26 \\
\hline
\end{tabular}

Sumber : Hasil Analisis, 2020

Sedangkan pada hari libur dari arah barat kecepatan kendaraan rata-rata yaitu kendaraan MC 39 km/jam, LV 37 km/jam, dan UM 23 km/jam. Untuk arah timur kecepatan rata-rata yaitu kendaraan MC 38 km/jam, LV 38 km/jam, dan UM $26 \mathrm{~km} / \mathrm{jam}$.

\section{Kinerja Ruas Jalan}

a. Kapasitas Jalan

Kapasitas ruas jalan merupakan arus lalu lintas maksimum yang dapat dipertahankan pada suatu bagian jalan dalam kondisi tertentu (Manual Kapasitas Jalan Indonesia, 1997). Dalam penelitian ini, analisa kapasitas jalan dihitung menggunakan rumus yang terdapat dalam MKJI 1997. Berikut hasil perhitungan kapasitas jalan pada jalan Ir.H Juanda Kota Sukabumi. 
Tabel 4. Perhitungan Kapasitas Jalan Ir.H Juanda

\begin{tabular}{lcc}
\hline \multirow{2}{*}{ Uraian } & \multicolumn{2}{c}{ Jalan Ir.H Juanda } \\
\cline { 2 - 3 } & Tanpa parkir & Dengan Parkir \\
\hline Kapasitas Dasar ( $\left.\mathrm{C}_{\mathrm{o}}\right)(\mathrm{Smp} / \mathrm{jam})$ & 3300 & 1650 \\
Lebar Lajur Efektif $\left(\mathrm{FC}_{\mathrm{w}}\right)$ & 1,08 & 0,92 \\
Pemisah Arah (FC & 1 & 1 \\
Hambatan Samping (FC & 0,89 & 0,89 \\
Ukuran Kota (FC & 0,90 (Juta & 0,90 \\
penduduk) & 2.854 & 1.215 \\
\multicolumn{1}{c}{ Kapasitas (C) } &
\end{tabular}

Sumber : Hasil Analisis, 2020

b. V/C Rasio

Analisis V/C Ratio dengan membandingkan jumlah volume kendaraan selama 1 jam dalam hal ini menggunakan volume jam tersibuk pada jalan Ir.H Juanda dibagi dengan kapasitas jalan. Dibawah ini merupakan V/C Ratio pada jalan Ir.H Juanda sebagai berikut.

Tabel 5. Perhitungan V/C Rasio

\begin{tabular}{lcc}
\hline \multicolumn{1}{c}{ Indikator } & \multicolumn{2}{c}{ Nilai } \\
\cline { 2 - 3 } & Tanpa parkir & Dengan parkir \\
\hline Volume (Smp/jam) & 642,1 & 642,1 \\
Kapasitas (Smp/Jam) & 2.854 & 1.215 \\
V/C Ratio & 0,22 & 0,53 \\
Tingkat pelayanan & $\mathrm{B}$ & $\mathrm{C}$ \\
\hline Sumber
\end{tabular}

Sumber : Hasil Analisis, 2020

c. Tingkat Pelayanan

Tingkat pelayanan jalan dihitung berdasarkan perbandingan antara volume dengan kapasitas. Tingkat pelayanan umumnya digunakan sebagai ukuran dari pengaruh yang membatasi akibat peningkatan. Tingkat pelayanan jalan atau Level Of Service (LOS) merupakan ukuran kinerja ruas jalan yang dihitung berdasarkan tingkat penggunaan jalan, kecepatan, kepadatan dan hambatan yang terjadi. Berdasarkan karakteristik tingkat pelayanan ruas jalan, maka pada ruas Jalan Ir.H. Juanda tingkat pelayanan jalannya adalah $\mathrm{C}$, dengan karakteristik sebagai berikut: Arus stabil tetapi pergerakan kendaraan dikendalikan oleh volume lalu lintas yang tinggi dengan kecepatan sekurangkurangnya 60 km/jam; Kepadatan lalu lintas sedang karena hambatan internal lalu lintas meningkat; Pengemudi memiliki keterbatasan untuk memilih kecepatan, pindah lajur atau mendahului.

\section{Karakteristik Parkir}

a. Volume Parkir

Volume parkir adalah jumlah kendaraan yang telah menggunakan ruang parkir pada suatu lahan parkir pada selang waktu tertentu dengan jumlah kendaraan masuk pada selang waktu tersebut dalam satu hari. Berdasarkan hasil survei selama 12 jam dapat diketahui volume parkir pada ruas Jalan Ir.H Juanda pada hari kerja untuk parkir MC berjumlah 155 kendaraan, dan parkir LV berjumlah 32 kendaraan. Hasil survei selama 12 jam dapat diketahui volume parkir pada 
ruas Jalan Ir.H Juanda pada hari libur untuk parkir MC berjumlah 160 kendaraan, dan parkir LV berjumlah 50 kendaraan.

b. Akumulasi Parkir

Akumulasi parkir merupakan informasi yang sangat dibutuhkan untuk mengetahui jumlah kendaraan yang sedang berada pada suatu lahan parkir pada selang waktu tertentu. Data ini dapat diperoleh dengan cara menjumlahkan kendaraan yang telah menggunakan lahan parkir ditambah dengan kendaraan yang masuk serta dikurangi dengan kendaraan yang keluar. Nilai akumulasi pada periode waktu 06.00-18.00 WIB untuk sepeda motor sebanyak 233 kendaraan, dan kendaraan ringan sebanyak 159 kendaraan. Berdasarkan hasil analisis diketahui bahwa akumulasi parkir tertinggi pada hari libur terjadi pada waktu 17.00-18.00 WIB dengan jumlah sepeda motor yaitu 215 kendaraan parkir dan kendaraan ringan sejumlah 40 kendaraan, dengan total akumulasi 255 kendaraan parkir.

c. Durasi Parkir

Durasi rata-rata lamanya parkir adalah waktu yang diperlukan atau lama parkir yang disebut juga sebagai durasi parkir. Durasi parkir merupakan informasi mengenai lamanya parkir kendaraan disuatu tempat parkir. Rata-rata lama waktu parkir kendaraan pada ruas jalan Ir.H Juanda untuk sepeda motor 32 menit atau 0,53 jam dan untuk mobil dengan waktu parkir 20 menit atau 0,33 jam.

Tabel 6. Durasi Parkir

\begin{tabular}{lcc}
\hline \multirow{2}{*}{ Durasi Parkir } & \multicolumn{2}{c}{ Jenis Kendaraan } \\
\cline { 2 - 3 } & Sepeda motor & Mobil \\
\hline Rata-rata (menit) & 32 & 20 \\
Rata-rata (Jam) & 0,53 & 0,33 \\
\hline
\end{tabular}

Sumber : Hasil Analisis, 2020

d. Petak Parkir

Berdasarkan observasi langsung ke lapangan, pengguna parkir mayoritas merupakan sepeda motor dan mobil penumpang jadi untuk perhitungan penelitian menghitung kendaraan sepeda motor dan mobil penumpang. Berikut merupakan perhitungan jumlah petak parkir yang dapat dibuat pada jalan Ir.H. Juanda Kota Sukabumi.

1. Sepeda Motor

Petak Parkir $=$ (Panjang jalan - Pengurangan Lahan Parkir)

SRP sepeda motor sudut $90^{\circ}$

$=(97 \mathrm{~m}-25 \mathrm{~m}) / 0,75$

$=96$ petak parkir

2. Mobil Penumpang

$$
\begin{aligned}
\text { Petak Parkir } & =\frac{(\text { Panjang jalan }- \text { Pengurangan Lahan Parkir })}{\text { SRP mobil penumpang sudut } 0^{\circ}} \\
& =(89 \mathrm{~m}-25 \mathrm{~m}) / 5 \\
& =13 \text { petak parkir }
\end{aligned}
$$


e. Kapasitas Parkir

Kapasitas Parkir merupakan kemampuan maksimum lahan parkir dalam menampung kendaraan. Analisis ini dilakukan dengan membandingkan jumlah petak parkir yang ada dengan rata-rata waktu parkir.

Tabel 7. Kapasitas Parkir

\begin{tabular}{cccc}
\hline Jenis Kendaraan & Jumlah Petak & $\begin{array}{c}\text { Durasi Parkir } \\
\text { (Jam) }\end{array}$ & $\begin{array}{c}\text { Kapasitas Statis } \\
\text { (Kend/Jam) }\end{array}$ \\
\hline Sepeda motor & 96 & 0,53 & 181 \\
\hline Mobil penumpang & 13 & 0,33 & 40 \\
\hline
\end{tabular}

Sumber : Hasil Analisis, 2020

f. Indeks Parkir

Indeks parkir adalah ukuran lain untuk menyatakan penggunaan pelataran parkir yang dinyatakan dalam persentase ruang yang ditempati oleh kendaraan parkir.

Tabel 8. Indeks Parkir

\begin{tabular}{cccc}
\hline Jenis Kendaraan & $\begin{array}{l}\text { Kapasitas } \\
\text { Statis (SRP) }\end{array}$ & $\begin{array}{c}\text { Akumulasi Maksimal } \\
\text { Kendaraan Parkir } \\
\text { (kend) }\end{array}$ & $\begin{array}{c}\text { Indeks } \\
\text { parkir }\end{array}$ \\
Sepeda motor & 181 & 233 & 1,97 \\
Mobil penumpang & 40 & 159 & 3,11 \\
\hline
\end{tabular}

Sumber : Hasil Analisis, 2020

Dari tabel diatas dapat disimpulkan bahwa indeks parkir pada jalan Ir.H. Juanda didapatkan indeks parkir IP $>1$ artinya bahwa fasilitas parkir bermasalah sebab kebutuhan parkir melebihi daya tampung/kapasias normal.

\section{Penentuan Penataan Parkir}

Untuk menentukan sudut yang digunakan perlu adanya kesesuaian dengan standar lebar minimum yang sudah ditentukan serta melihat bagaimana pengaruh terhadap kinerja jalan. Perlu dilakukan beberapa percobaan untuk menentukan sudut parkir sesuai dengan Jalan Ir.H Juanda Kota Sukabumi. Percobaan dilakukan dengan mengasumsikan kendaraan parkir berupa kendaraan pribadi roda 4 karena dimensi dari kendaraan yang lebih besar dibandingkan dengan kendaraan sepeda motor. Percobaan dalam penataan parkir pada Jalan Ir.H Juanda Kota Sukabumi sebagai berikut.

a. Sudut $0^{\circ}$

$$
\begin{array}{ll}
\text { Jumlah Petak } & =33 \\
\text { Lebar lajur efektif } & =5,3 \text { meter } \\
\text { Kapasitas } & =1.474 \\
\text { V/C Rasio } & =0,44 \\
\text { Tingkat pelayanan } & =\mathrm{B}
\end{array}
$$

b. Sudut $30^{\circ}$

$\begin{array}{ll}\text { Jumlah Petak } & =43 \\ \text { Lebar lajur efektif } & =3,3 \text { meter } \\ \text { Kapasitas } & =1.364 \\ \text { V/C Rasio } & =0,47 \\ \text { Tingkat pelayanan } & =C\end{array}$


C. Sudut $45^{\circ}$

Jumlah Petak

$=57$

Lebar lajur efektif

$=2,8$ meter

Kapasitas

$=1.256$

V/C Rasio

$=0,51$

Tingkat pelayanan $\quad=\mathrm{C}$

d. Sudut $60^{\circ}$

Jumlah Petak

$=68$

Lebar lajur efektif

$=1,9$ meter

Kapasitas

$=1.211$

V/C Rasio

$=0,53$

Tingkat pelayanan $=\mathrm{C}$

e. Sudut $90^{\circ}$

Jumlah Petak

$=87$

Lebar lajur efektif

$=1,8$ meter

Kapasitas

$=1.167$

V/C Rasio

$=0,55$

Tingkat pelayanan

$$
=\mathrm{C}
$$

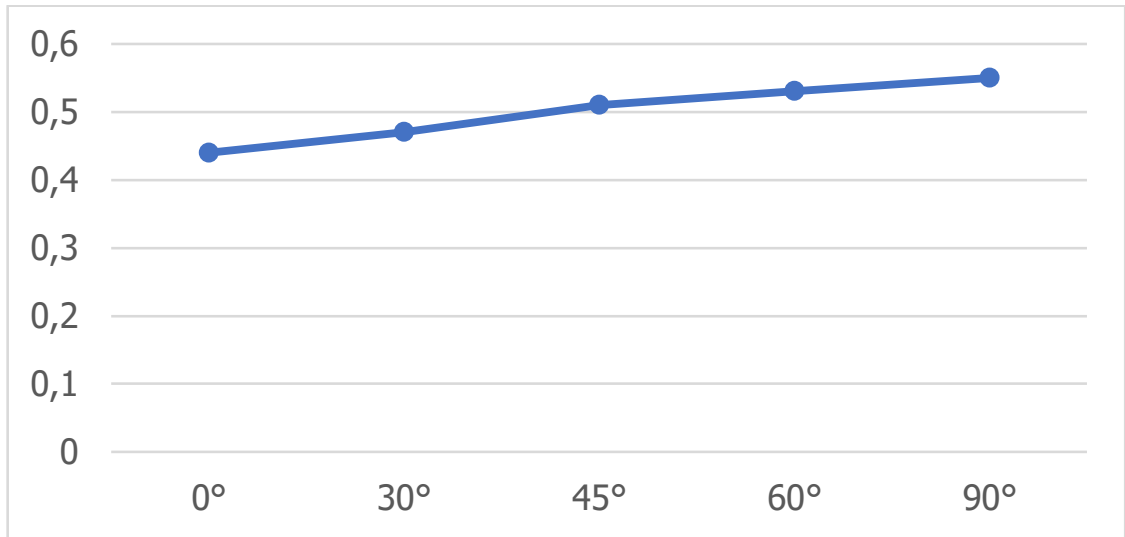

Gambar 2. Grafik Hubungan Sudut Parkir dengan V/C Rasio Berdasarkan grafik diatas dapat dilihat hubungan antara sudut parkir $0^{\circ}$, $30^{\circ}, 45^{\circ}, 60^{\circ}, 90^{\circ}$ dengan $\mathrm{v} / \mathrm{C}$ rasio. Dimana semakin besar sudut parkir yang digunakan maka semakin tinggi nilai v/c rasio, namun nilai kapasitas semakin rendah.

Tabel 9. Skenario Pengaturan Parkir dengan Menghilangkan Median

\begin{tabular}{ccccccc}
\hline No & Sudut Parkir & $\begin{array}{c}\text { Lebar } \\
\text { Lajur } \\
\text { Efektif }\end{array}$ & $\mathbf{V}$ & $\mathbf{C}$ & $\boldsymbol{V} / \boldsymbol{C}$ & $\begin{array}{c}\text { Tingkat } \\
\text { Pelayanan }\end{array}$ \\
\hline 1. & $0^{\circ}$ & 7,05 & 642,1 & 2.140 & 0,30 & $\mathrm{~B}$ \\
\hline 2. & $30^{\circ}$ & 6,05 & 642,1 & 1.974 & 0,32 & $\mathrm{~B}$ \\
\hline 3. & $45^{\circ}$ & 5,8 & 642,1 & 1.888 & 0,34 & $\mathrm{~B}$ \\
\hline 4. & $60^{\circ}$ & 5,3 & 642,1 & 1.198 & 0,53 & $\mathrm{C}$ \\
\hline 5. & $90^{\circ}$ & 5,3 & 642,1 & 1.167 & 0,55 & $\mathrm{C}$ \\
\hline
\end{tabular}

Sumber : Hasil Analisis, 2020 


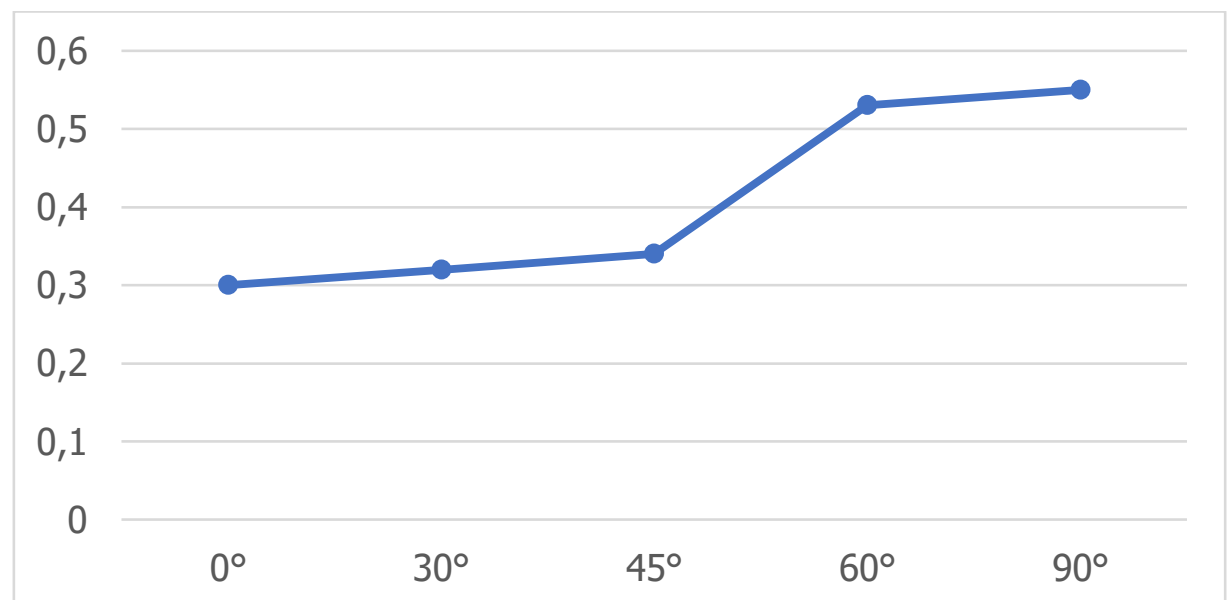

Gambar 3. Grafik Hubungan Sudut Parkir dan V/C Rasio dengan Menghilangkan Median

Pada grafik diatas merupakan hubungan antara sudut parkir dengan $\mathrm{v} / \mathrm{c}$ rasio ketika dihilangkan median. Dari hasil analisis diketahui semakin tinggi sudut parkir maka akan semakin tinggi nilai $\mathrm{v} / \mathrm{c}$ rasio.

Dengan perubahan sudut parkir dari $0^{\circ}$ menjadi $45^{\circ}$ maka memberikan dampak terhadap peningkatan kapasitas parkir. Dengan perubahan sudut parkir, maka lebar lajur efektif berkurang, namun kapasitas kendaraan parkir lebih banyak sehingga dapat memenuhi kebutuhan parkir yang tinggi pada jalan Ir.H Juanda. Dari hasil pengamatan yang dilakukan, 2 SRP kendaraan ringan dengan sudut $45^{\circ}$ dapat digunakan untuk 10 SRP sepeda motor. Jumlah SRP yang dibutuhkan untuk sepeda motor adalah 130 petak. Sehingga SRP yang tersedia adalah 135 petak SRP sepeda motor dan 30 SRP kendaraan ringan.

\section{SIMPULAN}

Berdasarkan analisis dan pembahasan yang telah dijelaskan maka dapat ditarik kesimpulan sebagai berikut : (a) Kondisi eksisiting pada ruas Jalan Ir.H Juanda, adanya parkir on street ternyata mempengaruhi kinerja ruas Jalan Ir.H. Juanda. Pada saat jam sibuk volume lalu lintas pada ruas jalan tersebut pada hari kerja adalah 642,1 smp/jam sedangkan pada hari libur adalah 209,1 smp/jam. Kapasitas ruas jalan tanpa parkir adalah $2.854 \mathrm{smp} / \mathrm{jam}$, sedangkan kapasitas dengan parkir adalah $1.215 \mathrm{smp} / \mathrm{jam}$. Untuk V/C Rasio sebesar 0,22. Kecepatan rata-rata $33 \mathrm{~km} / \mathrm{jam}$. Tingkat pelayanan untuk jam sibuk pada ruas Jalan Ir.H. Juanda adalah C; (b) Kinerja parkir pada jalan Ir.H Juanda pada kondisi eksisting saat ini hanya menggunakan salah satu sisi jalan. Pada sisi kanan jalan tidak memiliki kinerja parkir karena tidak diperuntukkan untuk parkir, hasil indeks parkir eksisting sepeda motor sebesar 1,97 dan mobil sebesar 3,11. Dapat diartikan bahwa fasilitas parkir bermasalah sebab kebutuhan parkir melebihi daya tampung/kapasitas normal. Sudut parkir pada ruas Jalan Ir.H Juanda diubah menjadi sudut $45^{\circ}$ dengan jumlah ruang parkir adalah 135 SRP sepeda motor dan 30 SRP kendaraan ringan. Fasilitas perlengkapan jalan pada ruas Jalan Ir.H Juanda merupakan jalan dengan kondisi geometrik yang lurus dan datar. Kondisi marka jalan dan rambu masih dalam keadaan baik hanya saja terdapat beberapa 
rambu yang tertutup pohon sehingga dapat mengurangi tingkat keselamatan pengguna jalan. Sehingga perlu adanya perawatan dan perbaikan untuk dapat meningkatkan keselamatan pada ruas Jalan Ir.H Juanda Kota Sukabumi.

\section{SARAN}

Dalam jangka pendek sebaiknya untuk menyiapkan kebijakan perparkiran berbasis tarif progresif dan batasan waktu parkir. Perlu dilakukan penertiban pada pengguna jalan yang melakukan parkir liar agar tidak memarkirkan kendaraannya secara sembarangan. Perlu dilakukan perawatan dan perbaikan rambu lalu lintas untuk mengurangi tingkat bahaya yang kemungkinan terjadi.

\section{DAFTAR PUSTAKA}

.2018. Kota Sukabumi. Peraturan Daerah Nomor 5 Tahun 2018 tentang Penyelenggaraan Perhubungan. Sukabumi: Pemerintah Daerah Kota Sukabumi

Departemen Pekerjaan Umum. 1997. Manual Kapasitas Jalan Indonesia (MKJI). Jakarta : Dirjen Bina Marga

Direktorat Jenderal Perhubungan Darat. 1998. Pedoman Perencanaan dan Pengoperasian Fasilitas Parkir. Jakarta: Departemen Perhubungan

Direktorat Jendral Perhubungan Darat. 1996. Pedoman Teknis Penyelenggaraan

Fasilitas Parkir. Jakarta: Departemen Perhubungan

Departemen Perhubungan. 2015. Manajemen dan Rekayasa Lalu Lintas. Jakarta : Departemen Perhubungan.

Badan Pusat Statistik.2018. Sukabumi : Badan Pusat Statistik

Kusmianingrum, Dani. 2010. Identifikasi Pengaruh Parkir di Badan Jalan terhadap Tingkat Pelayanan Jalan Ki Samaun Tangerang. Jakarta : Universitas Esa Unggul.

Puspitasari, Ketut Mudana. 2017. Kajian Penataan Parkir di Badan Jalan Kota Cirebon. Jakarta : Puslitbang Transportasi Jalan dan Perkeretaapian, Badan Penelitian dan Pengembangan Perhubungan.

Basri, Aisyah. 2017. Analisis Dampak Parkir Terhadap Kinerja Lalu Lintas Di Ruas Jalan sekitar Mall Panakkukang Kota Makasar. Makasar : UIN Alauddin.

Munawar, Ahmad. 2004. Manajemen Lalu Lintas Perkotaan. Yogyakarta: Beta Offset

Syarifuddin, Fauziah. 2017. Kebutuhan Parkir Pada Rumah Sakit Bhayangkara Di Kota Makasar. Makasar : UIN Alauddin.

Oktopianto, Y., \& Hidayat, D. W. (2020). Reflectivity Analysis and Maintenance Program of Road Markings IR . WIYOTO WIYONO Toll Road. Journal of Advanced Research in Dynamical and Control Systems, 12(02), 3118-3122. https://doi.org/10.5373/JARDCS/V12I2/S20201431

Warpani, Suwardjoko. 1990. Mernecanakan Sistem Perangkutan. Bandung. Institut Teknologi Bandung.

Yunianta, Andung. 2006. Pengaruh Manuver Kendaraan Parkir Badan Jalan Terhadap Karakteristik Lalu Lintas Di Jalan Diponegoro Yogyakarta. Semarang: Jurnal teknik Sipil. 